\title{
Standardization of Eleutherine bulbosa Urb. Bulbs and Total Flavonoid Content from Three Locations in Kalimantan, Indonesia
}

\author{
Rahmi Muthia ${ }^{1, *}$, Helmina Wati ${ }^{2}$, Wahyudin Bin Jamaludin ${ }^{3}$, Kartini $^{4}$, Finna Setiawan ${ }^{5}$, Muhammad Fikri', \\ Abdul Wahhab'
}

Rahmi Muthia ${ }^{1, *}$, Helmina Wati ${ }^{2}$, Wahyudin Bin Jamaludin ${ }^{3}$, Kartini $^{4}$, Finna Setiawan ${ }^{5}$, Muhammad Fikri' ${ }^{1}$, Abdul Wahhab'

'Departement of Pharmacognosy and Phytochemstry, Borneo Lestari College of Health Sciences, INDONESIA.

${ }^{2}$ Departement of Pharmacology, Borneo Lestari College of Health Sciences, INDONESIA.

${ }^{3}$ Departement of Pharmaceuticals, Borneo Lestari College of Health Sciences, INDONESIA.

${ }^{4}$ Pharmaceutical Biology Departement, Faculty of Pharmacy, Surabaya University, INDONESIA.

${ }^{5}$ Pharmacology Departement, Faculty of

Pharmacy, Surabaya University, INDONESIA.

\section{Correspondence}

\section{Rahmi Muthia}

Departement of Pharmacognosy and Phytochemstry, Borneo Lestari College of Health Sciences, INDONESIA.

E-mail : rahmimuth@gmail.com

\section{History}

- Submission Date: 15-10-2020;

- Review completed: 06-11-2020;

- Accepted Date: 11-11-2020.

DOI : 10.5530/pj.2021.13.11

Article Available online http://www.phcogj.com/v13/i1

\section{Copyright}

(C) 2021 Phcogj.Com. This is an openaccess article distributed under the terms of the Creative Commons Attribution 4.0 International license.

\begin{abstract}
Background: Dayak Onion (Eleutherine bulbosa Urb.) is a typical plant of Kalimantan which is traditionally used by the Dayak community as a medicinal plant. Dayak onion bulbs have been proven had many pharmacology activities. Objective: This study aims to determine the nonspesific and specific parameters of $70 \%$ ethanol extract of Eleutherine bulbosa Urb. Total flavonoids was also quantified Methods:. Eleutherine bulbosa Urb was extracted with maseration method used etanol $70 \%$ as solvent. Determination of non-spesific includes by determined specific gravity, water content, total ash content, acid insoluble ash content, residual sovents, heavy metanol contamination, microbial contamination, mold and yeast contamination. Determination of specific parameters included extract identity, organoleptic extract, water/ethanol soluble content, chromatography profile. Total flavonoid content were quantified with colorimetric method. Results: there were no significance difference between nonspesific and specific parameters Eleutherine bulbosa Urb from three different locations. Measurement of total phenol content and total flavonoid content respectively form South Borneo were ; 6,499 $\pm 0,5248 \mathrm{mg}$ QE/g extract, from central borneo were 7,585 $\pm 0,0437$ $\mathrm{mgQE} / \mathrm{g}$ extract, and from east borneo were $5,035 \mathrm{mg} \pm 0,3887 \mathrm{mgQE} / \mathrm{g}$ extract. Conclusion: it can be concluded that bulbs of Eleutherine bulbosa Urb from three locations have characters to similar between each other and bulbs of Eleutherine bulbosa Urb form central borneo had the highest total flavonoid content.
\end{abstract}

Key words: Eleutherine bulbosa Urb., Standardization, Non-specific parameters, Specific parameters, Flavonoids.

\section{INTRODUCTION}

The use of traditional medicines which has not been tested in the efficacy and safety of herbal medicines, cannot be used like modern medicine ${ }^{1}$. Considered herbal medicines have an important role in the health sector, it should be to determine the quality and safety standards of medicinal plants extracts ${ }^{2}$. Standardization of medicinal plant extracts is one of the important stages in the development of natural medicines ${ }^{3}$.

One of potential plants as medicine is the dayak onion (Eleutherine bulbosa Urb.). This plants contained secondary metabolites such as phenols, flavonoids, saponins, alkaloids, tannins and quinones ${ }^{4,5}$. Bulbs of this plant had many activites such as immunomodulator ${ }^{6-8}$, antiinflamation ${ }^{9}$, antioxidant ${ }^{10}$, antihypertention ${ }^{11}$, antyhipercholesterol ${ }^{4,12}$ and anticancer ${ }^{13}$.

To develop this potential, standardization of extracts were carried out. It consisted of nonspecific and spesicfic parameters ${ }^{14}$. Beside it, bulbs of Eleutherine bulbosa Urb. were examined for the organoleptic, macroscopic and microscopic parameters $^{15}$ Standardization of Eleutherine bulbosa Urb. bulbs had been carried out but from three different locations, that were Malang,
Bogor, and Purbalingga (Java Island) ${ }^{16}$ and also the standardization of this plant had been done used different solvent, thas was ethanol $96 \%$ which the plant only from east borneo ${ }^{17}$. Therefore this research needed to complete the standardization data for $70 \%$ ethanol extract of Eleutherine bulbosa Urb. bulbs and also to determined the total flavonoid content.

\section{MATERIALS AND METHODS}

\section{Plant collection}

Adult specimens of Eleutherine bulbosa Urb. plants were collected from three different location. The locations were Banjarbaru city, south borneo; palangkaraya city, central borneo and balikpapan city, east borneo. The sample were collected in the morning around 7-10 a.m. at Desember 2019. The collected plants were determinated at the Herbarium Bogoriense, Biology Research Center, Indonesian Institute of Sciences (LIPI), Bogor with number 2242/IPH.1.01/If.07/XII/2019. Manufacture of simplicia started with collected the bulbs as part of the Eleutherine bulbosa Urb. plants will be used, then sample will sorted and washed with running water. Then chopped and dried the sample under the sun at 7-10 a.m. The sample which had been dried, mashed with blender and sieved with mesh no. 16.

Cite this article: Muthia R, Wati H, Jamaludin WB, Kartini, Setiawan F, et al. Standardization of Eleutherine bulbosa Urb. Bulbs and Total Flavonoid Content from Three Locations in Kalimantan, Indonesia. Pharmacog J. 2021;13(1): 73-80. 


\section{Extraction}

The plant material was extracted with maceration method. The each dried and powdered plant material from three different location 500 grams was macerated with $1500 \mathrm{~mL} \mathrm{70 \%} \mathrm{ethanol} \mathrm{(1:3).} \mathrm{Soak} \mathrm{for}$ the first 6 hours, stirring occasionally. Then let stand for 18 hours. Repeat the remaseration process twice. All maserat were collected then concentrated used rotavapor at $50^{\circ} \mathrm{C}$ with $40 \mathrm{rpm}$. Furthermore evaporated it used waterbath at $50^{\circ} \mathrm{C}$ until thick extracts were obtained ${ }^{18}$. Calculated the yield of the thick extract.

Determination spesific parameter of $70 \%$ ethanol extract of Eleutherine bulbosa Urb. Bulbs

\section{Extract Identity}

Determination by doing nomenclature description includes extract names, Latin names of plants (botanical systematic), parts of plants used and names of local plants ${ }^{14}$.

\section{Macroscopic and Organoleptic Extract}

Observations were carried out with the five senses to describe the shape, color, taste and odor of the extract ${ }^{14}$. The statements "odorless", "practically odorless", "a faint characteristic odor", or variations there of, were determined by observation after the material has been exposed to the air for 15 minutes. Freshly opened package of apportion of about 25 $\mathrm{g}$ of the article to an open evaporating dish of about $100 \mathrm{ml}$ capacity ${ }^{15,18}$.

\section{Microscopic Test}

This test used aquabidest reagent. Powder microscopy was also carried out and the specific characteristic were recorded ${ }^{23}$. Plant parts that can be observed include starch, transport bundles, endodermis, epidermis and parenchyma tissue ${ }^{21}$.

\section{Water/Ethanol Soluble Content}

Determination was done by permeating $1.0 \mathrm{~g}$ extract with $25 \mathrm{~mL}$ waterchloroform (39: 1) for 24 hours, while shaking it repeatedly during the first 6 hours. Then allowed to stand for 18 hours and filtered. The filtrate is evaporated, the residue was heated at $105^{\circ} \mathrm{C}$ until the weight remained. Replicated 3 times. For Ethanol soluble content, the solvent used $96 \%$ ethanol $2,18,20$

\section{Chromatography Profile}

The method used Thin Layer Chromatography used n-hexane: ethyl acetate $(7: 3 \mathrm{v} / \mathrm{v})$ as a mobile phase and silica gel $60 \mathrm{GF}_{254}$ as a stationary phase. Bottle extract with a concentration of $0.5 \%$ TLC plate GF254 with a size of $8 \times 1.5 \mathrm{~cm}$ with a distance of $1 \mathrm{~cm}$ from the bottom edge and $0.5 \mathrm{~cm}$ from the top edge. Spotted on UV light of $254 \mathrm{~nm}$ and 366 $\mathrm{nm}$. Sprayed with $10 \%$ sulfuric acid $\left(\mathrm{H}_{2} \mathrm{SO}_{4}\right)$ solution in methanol ${ }^{18}$.

Determination Non Spesific Parameter of $70 \%$ ethanol extract of Eleutherine bulbosa Urb. Bulbs

\section{Specific gravity}

The $1 \mathrm{~g}$ extract was diluted by $5 \%$ with $70 \%$ ethanol. Empty pycnometer is weighed then added with water at $25 \mathrm{oC}$ weighed by water weight. Liquid extracts at $20^{\circ} \mathrm{C}$ are introduced, adjusted at $25^{\circ} \mathrm{C}$ and weighed ${ }^{14}$.

\section{Water content}

Determination is done by distillation. A total of $5 \mathrm{~g}$ of extract was put into a round bottom flask and $200 \mathrm{ml}$ of xylol which had been saturated with water and then heated at a temperature of $110^{\circ} \mathrm{C}$ for 1 hour. After the layers separate completely, the volume of water is read and calculated ${ }^{14,19}$. Water content is calculated in $\% \mathrm{v} / \mathrm{w}^{20}$.

\section{Total ash content}

Accurately $2 \mathrm{~g}$ of the extract was put into the silicate crucible then heated with a hot plate followed by a furnace at $650^{\circ} \mathrm{C}$ until the charcoal was used up. After that, the silicate crucible weighed after cooled to room temperature in a desiccator then calculated the results, expressed $\% \mathrm{w} / \mathrm{w}^{14,15}$

\section{Acid insoluble ash content}

The ash obtained as directed under Total Ash Content was boiled with $25 \mathrm{ml}$ of dilute sulfuric acid P for 5 minutes, the acid insoluble part was collected, the filtered ash was filtered with ash-free filter paper, washed with hot water, put into a silicate crucible, glowed with a furnace at a temperature of $650^{\circ} \mathrm{C}$ to charcoal was gone. Acid insoluble ash content was calculated to the material weight in $\% \mathrm{w} / \mathrm{w}^{14,15}$

\section{Residual solvent}

Concentrated extract was diluted to a concentration of $0.1 \%$ with methanol as a solvent. Samples were injected into the GC-MS at temperatures of $70^{\circ} \mathrm{C}$ to $200^{\circ} \mathrm{C}$. Analysis of the presence of ethanol gropus through the similar index and the re resulting cromatogram pattern $^{14,21}$

\section{Heavy metal contamination}

The instrument used to perform this test was Atomic Absorption Spectrophotometry (AAS) with the calibration curve method. Create a standard curve for lead $(\mathrm{Pb})$ and Cadmium $(\mathrm{Cd})$ with a concentration of $1000 \mathrm{ppm}$. Dilution was carried out gradually until a contentration of $1 \mathrm{ppm}$ was obtained. Series levels of 1, 5, 10 and $15 \mathrm{ppm}$ for lead $(\mathrm{Pb})$ and 0,$2 ; 0,4 ; 0,6$ and $1 \mathrm{ppm}$ for Cadmium (Cd) were made. Concentration of the sample solution was measured after absorption ${ }^{21}$. Weighed $2.5 \mathrm{~g}$ of extract and added $20 \mathrm{ml}$ of concentrated $\mathrm{HNO}_{3}$ and allowed to stand for 24 hours, heated to $100^{\circ} \mathrm{C}$ for 10 minutes then cooled then added $2 \mathrm{ml}$ of $30 \% \mathrm{H}_{2} \mathrm{O}_{2}$, heated until a clear yellow solution and filtered to a 50 volumetric flask and added aquadest until border mark. Samples were measured by means of AAS then heavy metal content was calculated $^{22}$.

\section{Microbial contamination}

Pipette $1 \mathrm{ml}$ from each dilution into a sterile (duplo) petri dish. Plate Count Agar (PCA) media was poured as much as $5 \mathrm{ml}$ into each petri dish which had been melted at $45^{\circ} \mathrm{C}$. Leave it until the mixture is frozen and put in an incubator cabinet at $37^{\circ} \mathrm{C}$ for 48 hours in an upside down position. Colony growth was recorded after 24 hours $^{2,21}$ Observed and counted the number of colonies that growth on petri dish.

\section{Mold and yeast contamination}

In a sterile (duplo) petri dish, $5 \mathrm{ml}$ of diluted Potato Dextrose Agar (PDA) media was poured at $45^{\circ} \mathrm{C}$, then $1 \mathrm{ml}$ was pipetted from each dilution. Leave to freeze in a saucer and incubated at room temperature or $25^{\circ} \mathrm{C}$ for 7 days. Results recorded ${ }^{2,21}$.

\section{Total Flavonoid Content}

Total flavonoid content was determined by aluminium chloride spectrophotometric method.

\section{Determination of The Maximum Quercetin Wavelength}

$0.5 \mathrm{~mL}$ of a quercetin solution with concentration $60 \mu \mathrm{g} / \mathrm{mL}$ added to the vial. Then added $0.1 \mathrm{~mL} \mathrm{AlCl}, 0.1 \mathrm{~mL}$ of sodium acetate $1 \mathrm{M}$ and $2.8 \mathrm{~mL}$ aquadest, shaken and read the absorbance at a wavelength of $400-600 \mathrm{~nm}^{24}$. 


\section{Determination of Operating Time}

$0.5 \mathrm{~mL}$ of a quercetin solution with concentration $60 \mu \mathrm{g} / \mathrm{mL}$ added to the vial. Then added $0.1 \mathrm{~mL} \mathrm{AlCl}_{3}, 0.1 \mathrm{~mL}$ of sodium acetate $1 \mathrm{M}$ and $2.8 \mathrm{~mL}$ aquadest, shaken and read the absorbance continuously at intervals 3 minutes for 60 minutes ${ }^{25}$.

\section{Quercetin Standard Curve}

Quercetin was used to make a standard calibration curve. $100 \mathrm{mg}$ quercetin was dissolved in $100 \mathrm{~mL}$ of ethanol $(1000 \mu \mathrm{g} / \mathrm{mL})$ and then diluted to get the concentration $20,30,40,50,60 \mu \mathrm{g} / \mathrm{mL} .0 .5 \mathrm{~mL}$ of each solution diluted standard solutions were pipette out and added with $0.1 \mathrm{~mL} \mathrm{AlCl}, 0.1 \mathrm{~mL}$ sodium acetate $1 \mathrm{M}$ and $2.8 \mathrm{~mL}$ aquadest then shake it to stand for operating time and read the absorbance at the maximum wavelength ${ }^{25}$.

\section{Determination of Total Flavonoid Content}

$0.5 \mathrm{~mL}$ extract solution with concentration $1000 \mu \mathrm{g} / \mathrm{mL}$ was added to the vial, added with $0.1 \mathrm{~mL} \mathrm{AlCl}, 0.1 \mathrm{~mL}$ sodium acetate $1 \mathrm{M}$ and 2.8 $\mathrm{mL}$ aquadest, then shaken and allowed to stand during operating time and read the absorbance at the maximum wavelength obtained ${ }^{24}$.

\section{RESULTS AND DISCUSSION}

In this study, bulbs of Eleutherine bulbosa Urb. extracted with maseration method used $70 \%$ ethanol. The yield extraction of sample from three locations presented at Table 1 . Standardization of medicinal plants is an important step in conducting research and development of natural medicines to ensure the quality and safety of drug preparations ${ }^{15}$. Spesific parameter of $70 \%$ ethanol extract of bulbs of Eleutherine bulbosa Urb. tested consist of extract identity, organoleptic extract, microscopic test, water/ethanol soluble content and chromatography profile.

Previous research results, the yield extract from Melak, West Kutai district, East Kalimantan used $96 \%$ ethanol as solvent produced yield $1,49 \% \mathrm{w} / \mathrm{w}^{16}$. Based on these research, the yield used $70 \%$ ethanol was greater than $96 \%$ ethanol. This result because the polarity level of $70 \%$ ethanol higher than $96 \%$ ethanol so that was able to atrracted more compounds.
Specific parameter desribe the identity an extract. The identification process is an important part of quality control of traditional medicine product because ingredients usually come from different cultivated areas, and have many physical similarities with other plants that are still of the same genus. The first parameter determined was extract identity. With the extract identity, it can be a specific clue to differentiate between plant extracts from one another. Then the organoleptic determination of the extract was the second step to check the quality of the extract by obsercing color, staste and odor. Water soluble content or ethanol soluble content were the next test. Each plant contains different compound, which of these chemical sbstances can be dissolved or attracted based on their respective polarity. In the Table 2, showed extract from three location were more soluble in ethanol compared water so it can be concluded the attracted compound were semipolar. The results of spesific parameter of extract identity, organoleptic and water/ethanol soluble content presented of Table 2 .

Macroscopic and microscopic characters are one of the important criteria for identification ${ }^{25}$. Bulbs of Eleutherine bulbosa Urb between three location Kalimantan have the save from. The sample have whole bulbs in groups, each group consists of several bulb, part of bulb base is hard, the bulb surface is smooth, pointed ends and have oval form. At microscopic characters between three location have similarity, their have parenchyma with oil drops and isolated schlerencyma. The results of spesific parameter of macroscopic and microscopic presented of Figures 1 and 2 .

The next parameter in extract standardization is chromatography profile.The determination of the chromatogram pattern was carried out by the TLC method which aimed to ceparated the compounds in the extract based on spot pattern and color after being observed on UV light and $\mathrm{H}_{2} \mathrm{SO}_{4}$ as spray reagents. The TLC profile is a qualitative analysis to show the presence of chemical compounds present in the sample ${ }^{19}$ The results showed there are four spot in TLC plate. The results of spesific parameter of TLC profile presented of Figure 3.

Non spesific parameter of $70 \%$ ethanol extract of Eleutherine bulbosa Urb Bulbs tested consist of specific gravity, water content, total ash content, acid insoluble ash content, residual solvent, heavy metal

Table 1: The Yield Extraction of $70 \%$ ethanol extact of Eleutherine bulbosa Urb. Bulbs from 3 Location.

\begin{tabular}{lcccc}
\hline \multirow{2}{*}{ No } & Location & Simplicia & \multicolumn{2}{c}{ Extract weights } \\
\cline { 2 - 5 } & Unit & Gram & Gram & Yield \\
\hline 1 & Banjarbaru city, south kalimantan & 500 & 53,491 & 10,69 \\
2 & Palangkaraya city, central kalimantan & 500 & 50,573 & 10,11 \\
3 & Balikpapan city, east kalimantan & 500 & 53,922 \\
\hline
\end{tabular}

Table 2: Spesific Parameter Results of 70\% Ethanol Extract of Eleutherine bulbosa Urb. Bulbs from 3 Location.

\begin{tabular}{|c|c|c|c|c|}
\hline No & Parameter & $\begin{array}{c}\text { Banjarbaru city, south } \\
\text { kalimantan }\end{array}$ & $\begin{array}{l}\text { Palangkaraya city, central } \\
\text { kalimantan }\end{array}$ & $\begin{array}{c}\text { Balikpapan city, east } \\
\text { kalimantan }\end{array}$ \\
\hline \multirow[t]{5}{*}{1} & Extract identity & & & \\
\hline & $\rightarrow$ Extract name & & Eleutherine bulbosa extract & \\
\hline & $\rightarrow$ Latin name & & Eleutherine bulbosa Urb. & \\
\hline & $\rightarrow$ Part of plant & & Bulbs & \\
\hline & $\rightarrow$ Local name & Bawang dayak & Bawang dayak & Bawang tiwai \\
\hline \multirow[t]{4}{*}{2} & Organoleptic & & & \\
\hline & $\rightarrow$ Color & & Brownish red & \\
\hline & $\rightarrow$ Taste & & Bitter & \\
\hline & $\rightarrow$ Odor & & Faint characteristic odor & \\
\hline \multirow[t]{2}{*}{3} & Water Soluble Content (\% w/w) & $33,34 \pm 1,78$ & $30,65 \pm 1,54^{*}$ & $31,52 \pm 0,98^{*}$ \\
\hline & Ethanol Soluble Content (\% w/w) & $83,13+1,67$ & $81,05 \pm 1,19^{*}$ & $81,22 \pm 1,99^{*}$ \\
\hline
\end{tabular}

*Values are means of triplicate determination \pm standard deviation 


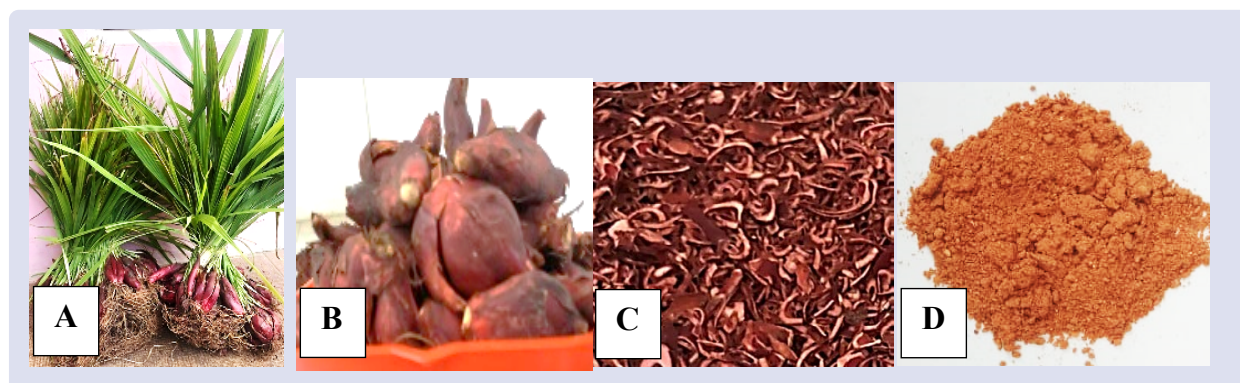

Figure 1: Macroscopic of Eleutherine bulbosa Urb. (A) Eleutherine bulbosa Urb Plants (B) Bulbs (C) Simplicia of Eleutherine bulbosa Urb (D) Powdered Bulbs.
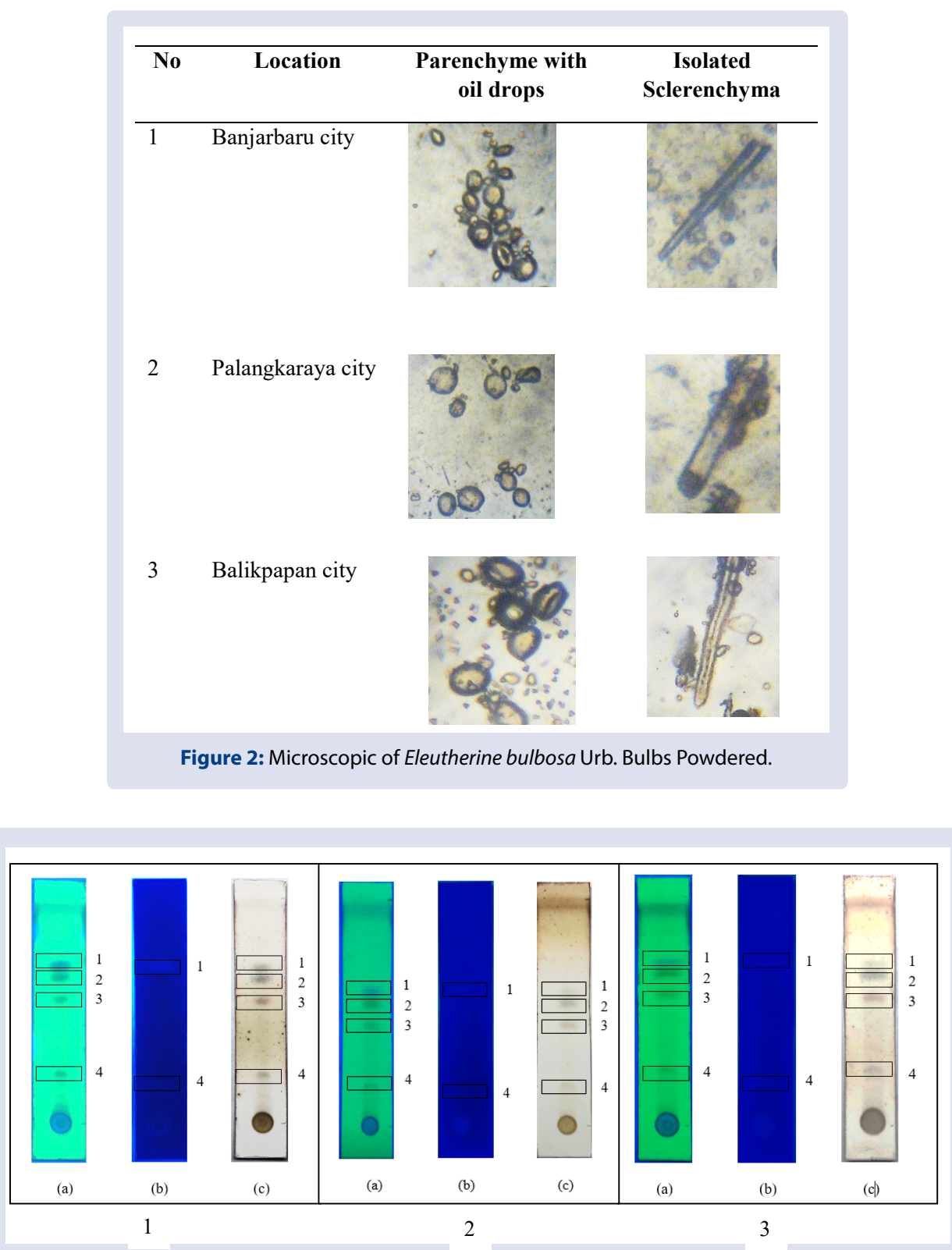

Figure 3: TLC Profile 70\% ethanol extract of Eleutherine bulbosa Urb Bulbs (1) Banjarbaru City (2) Palangkaraya city (3) Balikpapan city. Mobile phase : $n$-hexane : ethyl acetate (7:3). Stationary phase : Silica gel $60 \mathrm{GF}_{254^{*}}$ 
contamination $(\mathrm{Pb}$ dan $\mathrm{Cd})$, microbial contamintation and mold yeast contamination. The result showed at Table 3 .

Specific gravity relates to purity and contamination. These results spesific gravity from three location almost the same with the result of previous resarch from fridayanti et. al., that was $0,9347 \pm 0,00^{16}$. In this research, determination of water content used destilation method. The results appropriate requirment but its value almost value standard. One of the reason it can be happen because the solvent used was $70 \%$ ethanol which contains a high water content.

Next determination were total ash cotent and acid insoluble ash content. This determination aims to provide an overview of the internal and external mineral content originated from the initial process until the extract formed ${ }^{13}$. At this stage the extract was heated until the organic compounds and their derivatives are destructed and evaporated until only the mineral and inorganic elements remain. Another nonspecific parameter was determined the residual solvent. If the residual solvent still high in the extract, it is possible to enter the body and give the side effect $^{2}$. This method used GC-MS for analyze. Based on chromatogram pattern, the sample from three location proven negative.

Heavy metal contamination determination aims to ensure that the extract does not contain certain heavy metal exceeding the specified values which are harmful to health. Two heavy metals tested were lead
$(\mathrm{Pb})$ and cadmium $(\mathrm{Cd})$. Based on the result, the extracts accordance with the requirment. And the last non specific parameter were microbial contamination, mold and yeast contamination. This parameter aims to provide assurance that the extract does not contain microbes, mold and yeast exceed the requirment because it affects the stability of extract and harmful to healthy ${ }^{13}$. In this determination, the extract also accondace with the requirment.

Based on metabolit secondary and activity from Eleutherine bulbosa Urb, total flavonoid content was determined. In this method used quercetin as standard. The results for maximum wavelength was 435 $\mathrm{nm}$, with operating time 30 minutes $^{26}$. The maximum wavelength accordance with literature that stated the wavelength maximum for quercetin with this method was $415-440 \mathrm{~nm}^{26}$.

Quercetin standard curve have regression $\mathrm{y}=0,0132 \mathrm{x}+0,0152, \mathrm{R}^{2}=$ 0,9998. Quercetin standard curve showed at Figure 4. Total flavonoid content used aluminium chloride as reagent. $\mathrm{AlCl}_{3}$ will reacted with C-4 at ketone group and C-3 or C-5 at hydroxyl group from flavonoid structure ${ }^{28}$. The reaction between $\mathrm{AlCl}_{3}$ and quercetion showed at Figure 5. Furthermore determination of total flavonoid content for Eleutherine bulbosa Urb from three location. The result for total flavonoid content presented at Table 4 showed the highest total flavonoid content from palangkaraya city as 7,585 $\pm 0,0437 \mathrm{mg}$ QE/g extract. Eventhough the

Table 3: The Result of Non Spesific Parameter of 70\% ethanol extract of Eleutherine bulbosa Urb Bulbs from 3 Location.

\begin{tabular}{|c|c|c|c|c|c|}
\hline \multirow[t]{2}{*}{ No } & \multirow[t]{2}{*}{ Parameter } & \multicolumn{3}{|c|}{ Location } & \multirow[t]{2}{*}{ Requirment } \\
\hline & & Banjarbaru City & Palangkaraya City & Balikpapan city & \\
\hline 1 & Specific Gravity $(\mathrm{gram} / \mathrm{mL})^{\star}$ & $0,9140 \pm 0,00$ & $0,9155 \pm 0,00$ & $0,9126 \pm 0,00$ & - \\
\hline 2 & Water Content $(\% \mathrm{w} / \mathrm{w} /)^{*}$ & $9,945 \pm 0,04$ & $9,795 \pm 0,04$ & $9,945 \pm 0,03$ & $\leq 10,0 \%$ \\
\hline 3 & Total Ash Content $(\%)^{*}$ & $5,48 \pm 0,01$ & $5,67 \pm 0,04$ & $7,03 \pm 0,13$ & - \\
\hline 4 & $\begin{array}{l}\text { Acid Insoluble Ash Content (\% } \\
\mathrm{w} / \mathrm{w})^{*}\end{array}$ & $0,135 \pm 0,04$ & $0,165 \pm 0,00$ & $0,45 \pm 0,00$ & - \\
\hline 5 & Residual Solvent & Negative & Negative & Negative & Negative \\
\hline \multirow[t]{2}{*}{6} & $\begin{array}{l}\text { Heavy Metal Contamination - Pb } \\
(\mathrm{mg} / \mathrm{kg})^{*}\end{array}$ & $1,018 \pm 0,04$ & $2,003 \pm 0,04$ & $1,972 \pm 0,00$ & $10 \mathrm{mg} / \mathrm{kg}$ \\
\hline & $\begin{array}{l}\text { Heavy Metal Contamination - Cd } \\
(\mathrm{mg} / \mathrm{kg}) .^{*}\end{array}$ & $0,142 \pm 0,06$ & $0,144 \pm 0,01$ & $0,148 \pm 0,02$ & $0,3 \mathrm{mg} / \mathrm{kg}$ \\
\hline 7 & $\begin{array}{l}\text { Microbial Contamination } \\
(\text { colony } / \mathrm{g})^{*}\end{array}$ & $<01 \times 10^{\circ}$ & $<01 \times 10^{\circ}$ & $<01 \times 10^{0}$ & $\leq 10^{4}$ \\
\hline 8 & $\begin{array}{l}\text { Mold and Yeast Contamination } \\
(\text { colony } / \mathrm{g})^{*}\end{array}$ & $2,5 \times 10^{1}$ & $0,1 \times 10^{1}$ & $2,0 \times 10^{1}$ & $\leq 10^{3}$ \\
\hline
\end{tabular}

*Values are means of triplicate determination \pm Standard Deviation

Table 4: Total Flavonoid Content $70 \%$ ethanol extract of Eleutherine bulbosa Urb Bulbs from 3 Location.

\begin{tabular}{cccc}
\hline No & Location & Absorbance & Total Flavonoid Content (mg/g QE) \\
\hline 1 & Banjarbaru City & $0,101 \pm 0,0069$ & $6,499 \pm 0,5248$ \\
2 & Palangkaraya City & $0,115 \pm 0,0005$ & $7,585 \pm 0,0437$ \\
3 & Balikpapan City & $0,081 \pm 0,0051$ & $5,035 \pm 0,3887$ \\
\hline
\end{tabular}

${ }^{*}$ Values are means of triplicate determination \pm Standard Deviation

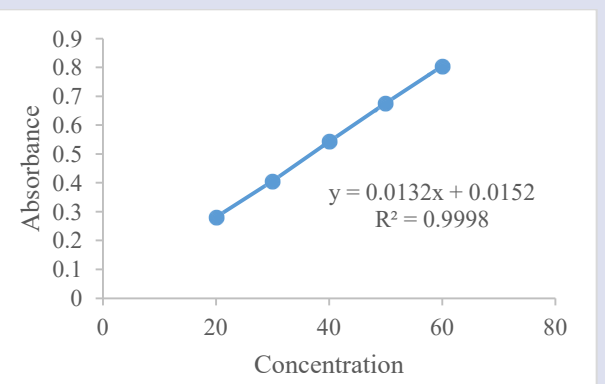

Figure 4: Quercetin Standard Curve Chart. 


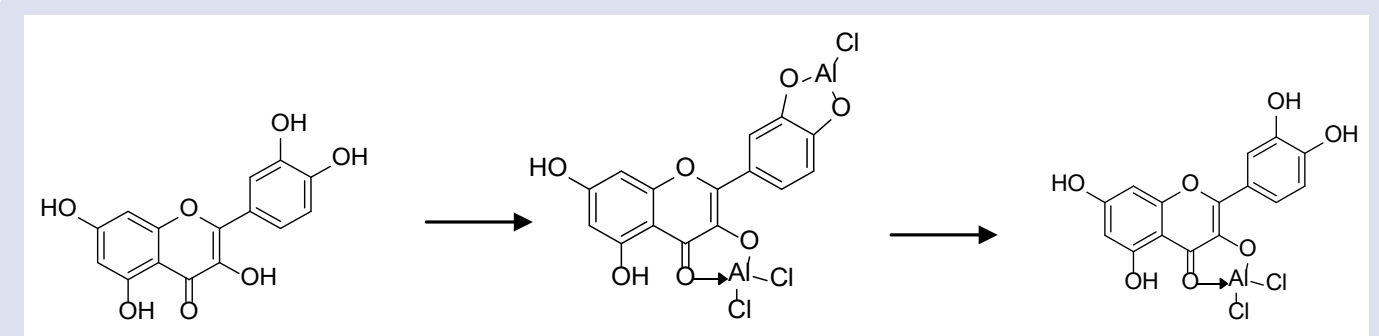

Figure 5: Quercetin - Aluminium Cholide Complex Compound.

sample have the same species, differences in the content of flavonoid compounds can be influenced by several factors such as genetics, the enviroment (climate, soil quality, water quality), the addition of growth support materials and harvest time ${ }^{2}$.

\section{CONCLUSION}

it can be concluded that bulbs of Eleutherine bulbosa Urb. from three locations on the nonspesific and specific parameters have characters to similar between each other and that bulbs of Eleutherine bulbosa Urb. form central borneo had the highest total flavonoid content.

\section{ACKNOWLEDGEMENTS}

The authors would like to acknowledge a research grant from Ministry of Research, Technology and Higher Education Republic of Indonesia (Kemenristekdikti) for the funding support of the research project ( Hibah Penelitian Kerja Sama Antar Perguruan Tinggi Nomor SPPK : 191/SP2H/AMD/LT/DRPM/2019) and we would thank to Banjarbaru Industry Standardization and Research Center which was involved in tested the standardization of extract of non-spesific parameters.

\section{REFERENCES}

1. BPOM RI. 2005. Standarisasi Ekstrak, Tumbuhan Obat Indonesia, Salah Satu Tahapan Penting Dalam Pengembangan Obat Asli Indonesia. Info POM. 6 (4): $1-12$

2. Saifudin, A., V. Rahayu, H. Y. Teruna. 2011. Standardisasi Bahan Obat Alam. Graha IImu, Yogyakarta.

3. Pine, A. T. D., G. Alam, F. Attamimi. 2015. Standardisasi Mutu Ekstrak Daun (Abelmoschus manihot (L.) Medik) dan Uji Efek Antikoksidan dengan Metode DPPH. JF FIK UINAM. 3(3): 111-128.

4. Wayan, J. Tandi, S. M. Sabang, F. Tibe. 2016. Uji Efek Ekstrak Etanol Bawang Dayak (Eleutherine bulbosa Mill. Urb.) Sebagai Antihiperkolesterolemia. Prosiding Seminar Nasional Tumbuhan Obat Indonesia. 50 (1): 41-50.

5. Sa'adah, H., H. Nurhasnawati, V. Permatasari. 2017. Pengaruh Metode Ekstraks Terhadap Kadar Flavonoid Ekstrak Etanol Umbi Bawang Dayak (Eleutherine palmifolia L. Merr.) Dengan Metode Spektrofotometri. Jurnal Borneo Journal of Pharmascientech. 1 (1): 1-9.

6. Muthia, R., \& Astuti, K. I. 2018. Efek Imunomodulator Infusa Umbi Bawang Dayak (Eleutherina palmifolia L. Merr. ) dengan Metode Bersihan Karbon. Jurnal Pharmascience. 5(1)): 63-70.

7. Utami, Aliyah, Y. P., \& Syukur, R. 2016. Uji Efek Imunostimulan Kombinas Ekstrak Mahkota Bunga kasumba Turate (Carthamus tinctorius L.) dan Ekstrak Umbi Bawang Dayak (Eleutherina palmifolia) pada mencit (mus musculus). JST Kesehatan. 6 (2): 179-184.

8. Meiliana, N. 2016. Pengaruh Pemberian Ekstrak Etanol Umbi Bawang Dayak (Eleutherina palmifolia L. Merr) Secara Oral pada Mencit Balb/C terhadap Pencegahan Penurunan Jumlah NK Sel dan CD8+. 2016. Jurnal Biosains Pascasarjana. 18.

9. Paramita S., \& Nuryanto, M. K. 2018. Anti-inflammatory Activity of Bawang Dayak (Eleutherine bulbosa (mill. Urb.)) Ethanol Bulb Extracts. Journal of Vocational Health Studies : 02(5)1-55.

10. Pratiwi dkk., 2013. The test of antioxidant activity from Bawang Mekah Leaves (Eleutherine americana Merr.) Using DPPH (2,2-Diphenyl-1-Picrylhydrazyl) Method. Trad. Med. J. 18 (1):9-16.
11. Rauf, A., S. Ningsi, F. Suhaidarwati. 2018. Uji Efek Ekstrak Etanol Bawang Dayak (Eleutherine Americana Merr.) Sebagai Antihipertensi Pada Tikus Jantan (Rattus Norvegicus). JF FIK UINAM. 6 (1): 55-65.

12. Kusuma, A.M., Y. Asarina1, Y.I. Rahmawati, Susanti. 2016. Efek Ekstrak Bawang Dayak (Eleutherine palmifolia (L.)Merr) dan Ubi Ungu (Ipomoea batatas L.) Terhadap Penurunan Kadar Kolesterol dan Trigliserida Darah pada Tikus Jantan. Jurnal Kefarmasian Indonesia. 6 (2): 108-116.

13. Putri, E. N. A. \& Haryoto. 2018. Aktivitas Antikanker Ekstrak Etanol Umb Bawang Dayak (Eleutherine americana Merr.) Terhadap Sel Kanker Payudara T47D. University Research Colloqium. 3(2): 192-203.

14. Depkes RI. 2000. Parameter Standar Umum Ekstrak Tumbuhan Obat. Departemen Kesehatan Republik Indonesia, Jakarta.

15. Budiastuti, Andini, W. W., Cahyasari, I. A., Primaharinastiti, R., Sukardiman 2020. Standardization Bark of Cinnamomum burmannii Nees Ex BI. From Five Areas of Indonesia. Pharmacogn J. 12(3) : 578-588.

16. Febriani, 2019. Standarisasi Ekstrak Etanol Umbi Bawang Dayak (Eleutherine palmifolia L. Merr) dari Tiga Daerah Berbeda [Skripsi]. Universitas Katolik Widya Mandala, Surabaya.

17. Fridayanti, A., Sastyarina, Y., Herman, Rahmadani, A., Firmansyah, G., Widyati, T. W., Nur, Y., Kuncoro, H., Wijayanti, E. 2017. Standarisasi Ekstrak Umbi Bawang Tiwai (Eleutherine americana (Aubl.) Merr.) Asal Kalimantan Timur. Proceeding og the 6th Mulawarman Pharmaceutical Conferences. ISSN : 2614-4778. Samarinda, 7-8 November 2017. Hal. 90-97.

18. Kementerian Kesehatan RI, 2017. Farmakope Herbal Indonesia Edisi II. Kementerian Kesehatan Republik Indonesia, Jakarta. Hal 531.

19. Rizaldi, G. 2019. Standardisasi Mutu Parameter Non Spesifik Ekstrak Etano Akar Saluang Belum (Luvunga sarmentosa Kurz). Skripsi. Program Studi S-1 Farmasi, Sekolah Tinggi IImu Kesehatan Borneo Lestari, Banjarbaru.

20. Husni, E., Ismed, F., Afriyandi, D. 2020. Standardization Study of Simplicia and Extract of Calamondin (Citrus microcarpa Bunge) Peel, Quantification of Hesperidin and Antibacterial Assay. Pharmacogn J. 12(4) : 777-783.

21. Hayati, F. Wibowo, A. Jumaryatno, P. Nugraha, A. T., Amalia, D. 2015 Standardisasi Ekstrak Daun Kangkung Darat (/pomoea reptans Poir) Hasil Bud Daya di Wilayah Sardonoharjo, Sleman dan Potensinya sebagai Antioksidan. Jurnal Imu Kefarmasian Indonesia. 13(2): 151-157.

22. Badan Standardisasi Nasional. Batas maksimum cemaran logam berat dalam pangan. Badan Standardisasi Nasional. SNI 7387:2009. 2-7.

23. Kumar, Shweta, Natarajan, B., Kanakamma, L. P., Ashis, T, P. \& Pawar, R.S. 2015 Pharmacognostical and Phytochemical evaluation of Ventilago calyculata Tul. (Bark). Pharmacogn J. 7(5) : 271-275.

24. Aryal, S., M. K. Baniya, K. Danekhu, P. Kunwar, R. Gurung, N. Koirala. 2019 Total Phenolic Content, Flavonoid Content and Antioxidant Potential of Wild Vegetables from Western Nepal. MDPI. 8(96): 1-12

25. Haeria., Hermawati, A. T. U. Pine. 2016. Penentuan Kadar Flavonoid Total dan Aktivitas Antioksidan Ekstrak Etanol Daun Bidara (Ziziphus spina-christi L.). Journal of Pharmaceutical and Medicinal Sciences. 1(2): 57-61.

26. Ekayanti, M., Ardiana, L., Najib, S.Z., Sauriasari, R., Elya, B. 2017. Pharmacognositc and Phytochemical Standardization of White Tea Leaf (Camellia sinensi L. Kuntze) Ethanolic Extracts. Pharmacogn J. 9(2) : 221-226.

27. Hassan, S. M., A. A. A. Aqil, M. Attimarad. 2013. Determination of Crude Saponin and Total Flavonoids Content in Guar Meal. Net Journals. 1(1): 24-28.

28. Kumalasari, E. \& N. Sulistyani. 2011. Aktivitas Antifungi Ekstrak Etanol Batang Binahong (Anredera cordifolia (Tenore) Steen.) Terhadap Candida Albicans Serta Skrinning Fitokimia. Jurnal Ilmiah Kefarmasian. 1(2): 51-62. 


\section{GRAPHICAL ABSTRACT}

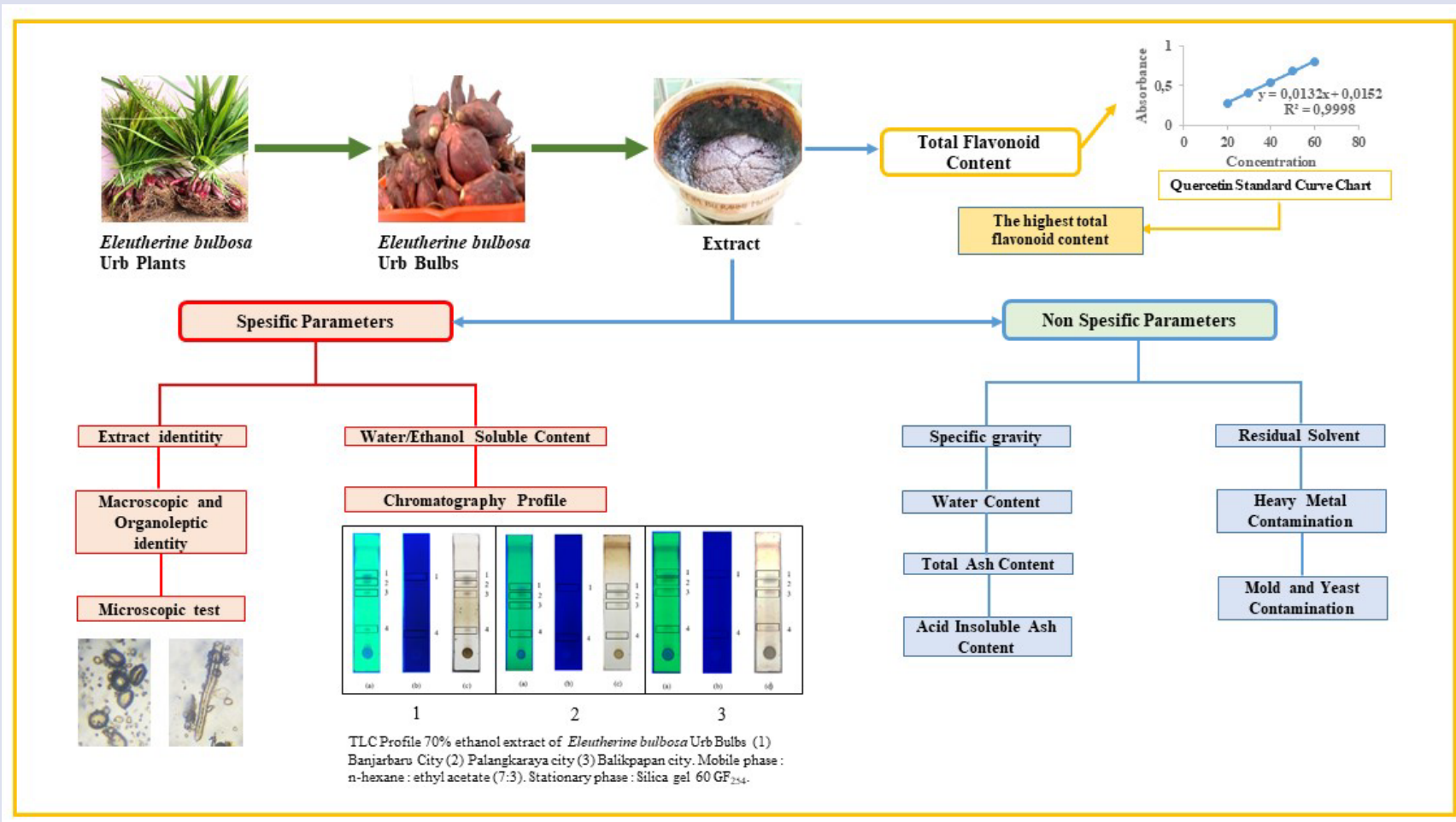

\section{ABOUT AUTHORS}

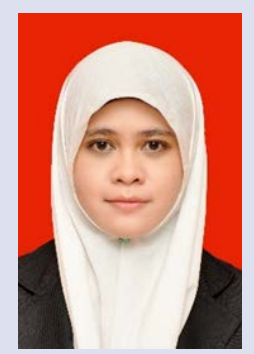

apt. Rahmi Muthia, M.Si. is an Assistant Professor in the Departement of Pharmacognosy and Phytochemistry, Sekolah Tinggi Ilmu Kesehatan Borneo Lestari Banjarbaru, Indonesia. She has completed her magister in Pharmaceutical Biology, School of Pharmacy, Bandung Institute of Technology. She works on development of natural materials especially simplicia characterization, standardization and in vitro activity test (antioxidant, immunomodulator, antihypertension).

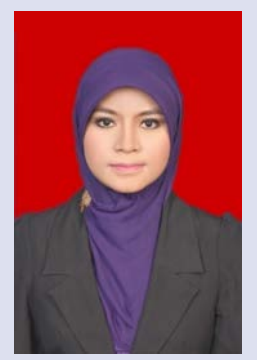

apt. Helmina Wati, M. Sc is an Assistant Professor in The Department of Pharmacy, Sekolah Tinggi Ilmu Kesehatan Borneo Lestari Banjarbaru, Indonesia. she has completed her magister in Clinical Pharmacy, Gadjah Mada University. She work in drug development in the field of pharmacology and clinical pharmacy.

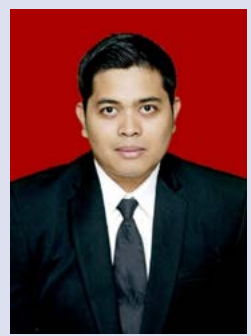

apt. Wahyudin Bin Jamaludin, M.Si. is lecturer in the Department of Pharmacy, Sekolah Tinggi IImu Kesehatan Borneo Lestari Banjarbaru, Indonesia. he has graduated his magister in Pharmaceutical from School of Pharmacy, Bandung Institute of Technology, Indonesia. He is currently working in projects develop modified delivery system of Indonesian medicinal plants. 


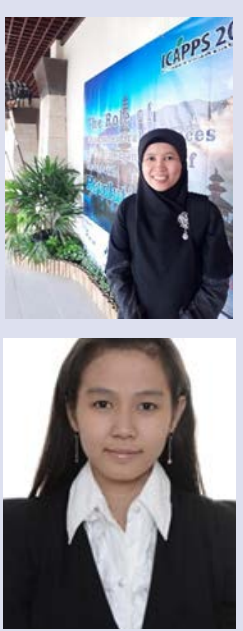

Kartini, Ph.D. is an Associate Professor in the Department of Pharmaceutical Biology, Faculty of Pharmacy, University of Surabaya, Indonesia. She has completed her Ph.D. in Phytopharmaceutical Sciences from Faculty of Graduate Studies Mahidol University, Thailand. She is currently the Director of Center for Traditional Medicine Information \& Development, Faculty of Pharmacy, University of Surabaya. She works on standardization of herbal medicines and its application as wound healing, anticancer, and immunomodulator.

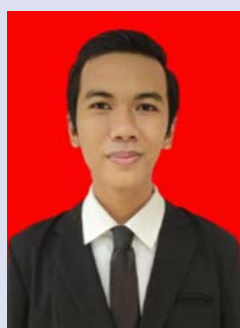

Dr. Finna Setiawan, M.Si. is an Assistant Professor in the Department of Pharmaceutical Biology, Faculty of Pharmacy, University of Surabaya, Indonesia. She has completed her Doctoral Programme in Pharmacology Sciences from Bandung Institute of Technology, Indonesia. She is currently working in bioactivity of herbal medicines especially in effectivity and safety use of herbal medicines.

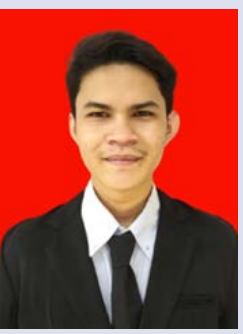

Muhammad Fikri, S. Farm is an Pharmacist Assistant. He has graduated his bachelor in Pharmacy, Sekolah Tinggi IImu Kesehatan Borneo Lestari Banjarbaru, Indonesia. He actively participates in the student creativity program by the Directorate of Higher Education every year and passed humans in 2016. He was a lecturer assistant for quantitative analysis of chemistry, microbiology-parasitology, phytochemistry, human physiological anatomy, and pharmacognosy.

Abdul Wahhab, S. Farm is an Pharmacist Assistant. He has graduated his bachelor in Pharmacy, Sekolah Tinggi Ilmu Kesehatan Borneo Lestari Banjarbaru, Indonesia. He was a lecturer assistant for quantitative analysis of chemistry, microbiology-parasitology, phytochemistry, human physiological anatomy, and pharmacognosy.

Cite this article: Muthia R, Wati H, Jamaludin WB, Kartini, Setiawan F, et al. Standardization of Eleutherine bulbosa Urb. Bulbs and Total Flavonoid Content from Three Locations in Kalimantan, Indonesia. Pharmacog J. 2021;13(1): 73-80. 